\title{
Perception of the sociology of absences in the agricultural machinery industry supply chain
}

\section{A percepção da sociologia das ausências na cadeia de suprimentos da indústria de máquinas agrícolas}

Paolo Edoardo Coti-Zelati ${ }^{1}$, Maria Luisa Mendes Teixeira² (1D, Michel Mott Machado ${ }^{3}$ (D), Davi Lucas Arruda de Araújo ${ }^{1,4}$ (1), Rafael Morais Pereira4,5 (1)

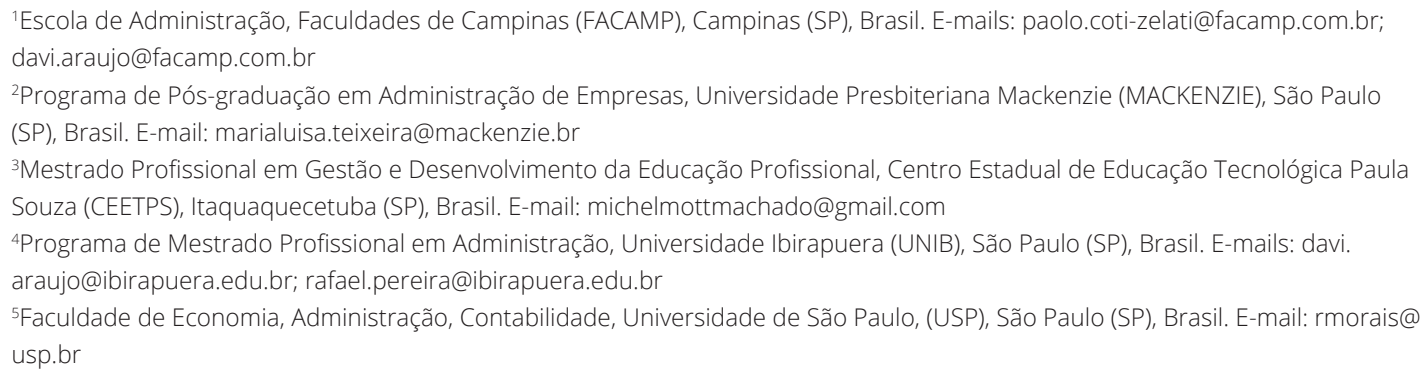

How to cite: Coti-Zelati, P. E., Teixeira, M. L. M., Machado, M. M., Araújo, D. L. A., \& Pereira, R. M. (2022). Perception of the sociology of absence in the agricultural machinery industry supply chain. Revista de Economia e Sociologia Rural, 60(4), e247901. https://doi.org/10.1590/1806-9479.2021.247901

\begin{abstract}
Studies on supply chain management have been focused on competitiveness from the alignment of suppliers to the company's main strategic interests, with the assumption that this alignment benefits all chains. In this approach, unmet interests of these suppliers are hidden when submitted to the subordination of the main company. This work aimed to understand how the supply chain of the agricultural machinery industry is managed, with the sociology of absences as a category of analysis. This is a descriptive and qualitative approach research, with the participation of six respondents, executives of companies providing implements for the three main agricultural machinery companies in the world. During the research, we sought to connect seven dimensions of supply chain management with the macro-sociological procedure of investigation of the sociology of absences. The results showed that the supply chain management of the agricultural machinery industry promotes the five non-logical existence (monocultures), putting smaller companies' supply chain members in a situation of absence and concealment, disregarding their knowledge and interests.
\end{abstract}

Keywords: supply chain, sociology of absences, agricultural industry.

Resumo: Os estudos sobre a gestão da cadeia de suprimentos têm tido como foco a competitividade a partir do alinhamento das empresas fornecedoras aos interesses estratégicos da empresa principal, tendo como pressuposto que esse alinhamento beneficia toda a cadeia. Nesta abordagem, ficam ocultos os interesses não atendidos dessas empresas fornecedoras ao se submeterem à subordinação da empresa principal. Este trabalho teve como objetivo compreender como a cadeia de suprimentos da indústria de máquinas agrícolas é gerenciada, tendo como categoria de análise a sociologia das ausências. A pesquisa, descritiva e de abordagem qualitativa, contou com a participação de seis entrevistados, executivos de empresas fornecedoras de implementos para as três principais empresas mundiais de máquinas agrícolas. Durante a pesquisa, relacionaram-se sete dimensões da gestão da cadeia de suprimentos com o procedimento macrossociológico de investigação da sociologia das ausências. Os resultados apontaram que a gestão da cadeia de suprimentos da indústria de máquinas agrícolas promove as cinco lógicas da não existência (monoculturas), colocando as empresas menores integrantes da cadeia de suprimentos em uma situação de ausência e ocultação, desconsiderando seus saberes e interesses.

Palavras-chave: gestão da cadeia de suprimentos, sociologia das ausências, máquinas agrícolas. 


\section{Introduction}

In recent years, the world has lived in a historical context of deep crisis and contradictions. From a systemic perspective, it is possible to view this crisis as interdependent symptoms of a cause crisis linked to the paradigmatic limits of a model of civilization and development that has been consolidated in the West in the last centuries and intensified in the last 30 years, with the predominance of Anglo-Saxon liberal capitalism who has endeavored to standardize humanity (Machado et al., 2012).

Taking into account the standardization model, based on the process of neoliberal globalization, it is possible to notice a social inability to generate wealth without generating, at the same time, exclusion and inequality, social violence, environmental degradation, and information manipulation and thought standardization (Boltanski \& Chiapello, 1999). From this scenario, the concept of sociology of absences emerges, based on the research of Prof. Boaventura de Sousa Santos, called "The reinvention of social emancipation"(Medeiros \& Teixeira, 2018, p. 170). Brazil is one of the countries where there are several significant conflicts between hegemonic and counter-hegemonic projects to neoliberal globalization. Therefore, it is believed that the thought of the Portuguese sociologist can point out alternatives for the understanding of organizational phenomena.

For Santos (2006), the sociology of absences is a macrosociological research procedure that seeks to point out that the sociocultural phenomenon that does not seem to exist had this "invisibility" actively produced by unfair and predatory social relations through mechanisms of concealment. Looking at the world through the lens of this macrosociological approach (sociology of absences), social scientific research aims to transform non-credible objects into credible ones, and hence to convert absences into emergencies.

In general, studies in supply chain management (SCM) are guided by the positivist approach of the modern paradigm and focus on the interests of companies that have greater power within the supply chain (captains). In this approach, the research object has inherent qualities that exist independently of the investigator. The understanding of truth is conceived by the theory of truth correspondence, that is, a roadmap between research statements and reality. For this epistemological basis, validity lies in data that truly and objectively measure reality (Comte, 1973; Weber, 2004).

According to Choi \& Wu (2009), studies promoted on SCM emphasize the initial relationship of any chain. As an example, we can mention the dyadic relationship between buyer and supplier, and in most of the research, the chain captain is one of these links. According to these authors, a dyadic relationship is important for supply chain studies, but it cannot solve all the problems related to SCM. Analyzing SCM through the sociology of absences may be an alternative to highlight relevant aspects, but initially not credible concerning what exists and is considered reliable by the mainstream in this line of research.

The central question that arises from this debate is: How is the supply chain of the agricultural machinery industry managed from the point of view of the sociology of absences? This is the basic context in which the present work was developed seeking to contribute to the strategy area, by proposing to understand how the supply chain of the agricultural machinery industry is managed, taking as its analysis the sociology of absences.

This article has been organized into five sections. In addition to this introduction, in section two, the theoretical framework on SCM and sociology of absences was developed. Section three describes the methodological procedures. Next, the results obtained were presented and analyzed. Finally, section five presents the conclusions of this research, as well as suggestions for future studies. 


\section{Theoretical Foundation}

\subsection{Sociology of Absences}

Observing the world through totalizing reason, one can see that modern science has set in motion a process where there is no understanding, no action that is not referred to as a whole, and this whole has priority over its component parts (Pizzio \& Veronese, 2008). The whole is represented by capitalism, man (white, educated, heterosexual, etc.), rich countries, and their agents. Any part of this whole that does not follow these parameters is led to the condition of social absence or an unqualified existence. Hence the need for a sociology of absences, naming agents, and marginalized knowledge to give them credibility, legitimate existence status as such, not waste or anachronism (Santos, 2004).

Recognizing and validating the absences found in society is a commitment of science adhering to the double epistemological rupture (Santos, 2000). For Veronese (2005), the first rupture occurred at the moment when common sense was banished from modern science to obtain its epistemological privileges. From this moment, much of humanity's knowledge has been dragged into the condition of absence. In a second moment, there is the rupture with the rupture itself, that is, the experiences merge again with common sense, considering it a relevant knowledge and impacting it to transform it and being transformed, in a dialectic productive alliances between different forms of knowledge (Veronese, 2005).

In this sense, according to Santos (2010b), the greater the multiplicity and diversity of experiences available and shared among agents, the greater will be the expansion of the present and future general experience. To this end, Santos (2002) lists five social fields where the proclaimed multiplicity and diversity will probably be revealed, which are:

(a) Knowledge experiences: they are inserted in the conflicts and dialogues existing in the different forms of knowledge. Experience emerges from biodiversities, such as modern and traditional medicine or biotechnology and indigenous knowledge.

(b) Experiences of development, work, and production: occur through dialogues and conflicts between different forms of production. Example: the capitalist mode of production and the sustainable development model as infinite growth.

(c) Recognition Experiences: born of possible dialogues and conflicts between social classification systems, the greatest example would be the dialogues and conflicts existing in social debates related to capitalism, racism, sexism, and xenophobia.

(d) Experiences of democracy: possible in the dialogue and conflict between the hegemonic democratic model (liberal democracy) and participatory democracy. Examples: forms of participatory deliberation in indigenous communities and citizen participation in decisions about scientific and technological impacts.

(e) Communication and information experiences: emerged from dialogues and conflicts arising from the technological revolution, communication and information, that is, between global information flow and global media. The most common example for this type of experience comes from the dialogue between transactional independent communication networks and independent alternative media.

In any case, for the intended emancipatory transformative action to take place, a certain work of epistemological imagination and democratic imagination is necessary, since "[...] the aim is to construct new and plural conceptions of social emancipation on the ruins of the automatic social emancipation of the modern project"(Santos, 2006, p. 134). Within this perspective, the translation work together with the sociology of absences and emergencies aims to develop an 
alternative to indolent reason that provides the waste of experience, or the multiplicity/diversity of experiences. The main objective of this proposed new epistemological and democratic imagination would be to "reinvent social emancipation"(Santos, 2006). According to Vieira \& Ramos (2018, p. 135), "[...] the sociology of absences presents the possibility of creation of a new way of looking at the social reality to understand/recognize many knowledge/experiences considered invisible/nonexistent by indolent reason".

It should be noted, however, that the vision of social emancipation in Boaventura Santos differs from the conception defended by the critical theory derived from modernity, since the latter, among other aspects, is based on a universalizing narrative goal (Machado \& Teixeira, 2017). Instead, what is intended is the transformation of unequal power relations into shared authority relations (Santos, 2010a), based on the proposition of a global repoliticization of social practice (Santos, 2010a). In this context, "[...] identify power relations and imagine practical ways of transforming them into relations of shared authority"(Santos, 2010a, p. 271). In fact, what Boaventura Santos proposes is a new theory of emancipation, whose notion has a strong democratic component, which could also be called a new democratic theory, which would be based on the articulation of representation and participation (Santos, 2010a). In this way, a process vision is imposed, not an end.

Concomitantly with the proposed new democratic theory, Boaventura Santos intends to develop what he calls a cosmopolitan reason (which would be the counterpoint to indolent reason), which would occur through the sociology of absences, the sociology of emergencies, and the work of translation.

It is noteworthy that indolent reason has as its central characteristics the proposition of generalizations, of an explanatory general theory, from the perspective of a Western understanding of the world, in which invariably there is a contraction of the present and an expansion of the future (Bernandes \& Ventura, 2017). This wasteful reason of experiences is based on two other main reasons, namely metonymic reason and proleptic reason (Santos, 2006). In this sense, it is assumed that there is absence production whenever "[...] a given entity is disqualified and made invisible, unintelligible or irreversibly discarded. What unites the different logics of non-existence production is that they are all manifestations of the same rational monoculture"(Santos, 2006, p. 102).

This rational monoculture would be formed by discriminatory logics, which can be considered modes of production of absences or non-existence, which would be: the monoculture of knowledge and scientific rigor; the monoculture of linear time; the monoculture of the naturalization of differences (logic of social classification); the logic of the dominant scale; and the monoculture of the capitalist productivity criteria (Santos, 2006).

Briefly speaking, according to Santos (2006), the monoculture of knowledge and the rigor of the scientific has to do with the production of the figure of the ignorant, as a form of social disqualification resulting from this discriminatory logic, because all knowledge that is not legitimized by the canons modern science and high culture, in terms of truth and aesthetic quality, respectively, will be discarded/invisible; the monoculture of linear time, in turn, is related to the idea that history has a linear, unique and known meaning, so that the knowledge, institutions and sociability of the central countries - it is thought that here too one could consider companies/organizations - from the world system would be ahead of time, so "what / who /"is not in this center, so it would be considered backward, underdeveloped, primitive, savage; the naturalization of difference consists in distributing the population into categories that tend to naturalize differences, such as race and gender/sex, and in this logic, those who do not align with the dominant criteria, therefore, are considered as inferior; the logic of the dominant scale 
in Western modernity appears as the universal and the global, and once a primordial scale is adopted, any other possible scale is soon irrelevant, thus producing the figure of the particular or the place; finally, there is the monoculture of the capitalist productivity criteria, which has to do with the imperative of not questioning the rational objective of the logic of economic growth, as a fundamental element in maximizing profit generation in a given production cycle. That, in this logic, non-existence is produced in the form of the unproductive, which, turned to nature, would be the same as sterility, and to work, laziness, or professional disqualification.

According to Paes \& Dellagnelo (2012), by deglobalizing the site in relation to hegemonic globalization, the sociology of absences also explores the possibility of counter-hegemonic globalization. It should be clarified that the metaphorical appropriation of the idea of monoculture serves to try to illustrate the predominance of metonymic reason and proleptic reason over any other, so that, as in agricultural monoculture, which uses land extensively for the production of a single product until its possibilities are exhausted, we think that the production of a single kind of thought, or way of seeing the world, causes the impoverishment of humanity (Ferrarini, 2018).

In opposition to this mono-cultural view of the world, the perspective of an ecology of knowledge, which can be understood as "a set of epistemologies that start from the possibility of diversity and counter-hegemonic globalization and aim to contribute to their credibility and strengthen"(Santos, 2006, p. 154). Thus, instead of the modes of production of absences, the ecologies of knowledge, temporalities, recognitions, transscales, and productivities would be replaced (Santos, 2006). In other words, it would be a way of seeking recognition of the plurality of diverse knowledge, their autonomy, as well as a possible articulation between them (Santos, 2006).

Also, according to Santos (2006, p. 142): "[...] the ecology of knowledge is the epistemology of the struggle against cognitive injustice [...], which would eventually privilege certain social groups over others. Moreover, in order to think of ecology of knowledge as a basis of reciprocity and recognition, as well as a willingness for mutual enrichment between cultures, that is, the establishment of horizontal relations must have the understanding that [...]. The recognition of the epistemological diversity of the world suggests that diversity is also cultural and ultimately ontological, translating into multiple conceptions of being in the world"

Thus, in order to carry out the intended expansion of epistemological diversity, two macrosociological procedures should be used, namely, the sociology of absences and the sociology of emergencies (Santos, 2006), and the first would seek "[...] to elucidate the mechanisms of concealment and discrimination of the diversity of experiences and existences in the world, denouncing the processes of disqualification of the other [...]"(Santos, 2006, p. 115); while the symbolic enlargement performed by the sociology of emergencies, "[...] aims to analyze in a given practice, experience or way of knowing what exists in it only as a future trend or possibility" (Santos, 2006, p. 120). To these two procedures would be added the so-called translation work procedure, which would allow one to "create reciprocal intelligibility between the experiences of the world, both available and possible, revealed by the sociology of absences and the sociology of emergencies"(Santos, 2006, p. 154).

Thus, by focusing more specifically on the sociology of absences - which in the present study is taken as the central interpretative concept - it should be emphasized that this is the procedure that aims to elucidate the existence of logics within a model of rationality that induces nonstocks (Machado et al., 2012). In this sense, this concept/procedure supposes an epistemological work of rescue so that we can understand, more clearly, the logic and legitimate knowledge, ignored by the hegemonic discourse because they are judged as primitive, inferior, particular, and unproductive (Mello, 2008). For Silva \& Moretto Neto (2016), the sociology of absences is 
configured as a macro-sociological procedure that refers to ecologies, which in turn overlap with monocultures that cause absences due to the silencing imposed by disqualification, marginalization, and exclusion.

Therefore, it is believed that in order to have fairer and more democratic societies, one must think about how to preserve the rights of minorities - which, through a transposition of thought/reality, includes organizations - to exist in the world with dignity in their relationships. It is in this sense that the principle of equality, the exercise of recognition of difference and historical diversity, is imposed, with a view to a process of social transformation that considers the ecology of knowledge and social practices, in place of cultural monocultures (Santos, 2006). To do so, it would be paramount to give voice to the traditionally marginalized or subordinate groups, that is, those that have been made absent or nonexistent from the social scene (Vieira \& Ramos, 2018).

Still following the path of Boaventura Santos 'intellectual path, it must be considered that the reinvention of social emancipation must admit the victims' experience, learning from the South, which would mean going beyond the critical theory produced by the North (Santos, 2006; Ferrarini, 2018) and what is sought, in this line, is exteriority to modernity, since the violence of colonialism was never included in its self-representation (Santos, 2006; Dussel, 2000; Mignolo, 2000). In this sense, it is thought that it would be pertinent to reflect on some of the possible implications of hegemonic globalization in the field of knowledge and management practices (Santiago \& Machado, 2015) since what tends to prevail is knowledge. Practices produced in the Global North out of their own hegemonic interests. While not all problems of ignorance are problems of absent knowledge, those that are can gain by an examination of the literature on absence and the concept of the privative (Croissant, 2014).

\subsection{Supply Chain Management (SCM)}

Discussions about supply chain management began in the 1980s and remain a key topic of interest for academic and executive careers. However, it was not until the late 1990s that the number of SCM research began to grow, taking a prominent place in studies related to organizational operations (Kouvelis et al., 2006).

Kopczak \& Johnson (2003) define a supply chain as two or more companies working together to plan and execute supply-related operations, being more successful than working in isolation, that is, supply chain collaboration is based on reciprocal objectives. SCM can be formed in the form of strategic alliances. These strategic alliances present themselves as usually long-term agreements between organizations. This modality goes beyond normal market transactions but is not a merger. The strategic alliance makes companies work together, but without losing independence and autonomy (Barney \& Hesterly, 2012).

The supply chain acts as a network of partnerships between manufacturers, suppliers of raw materials, carriers, retailers, or any other category (Simchi-Levi et al., 2010) and implies the systemic and strategic coordination of traditional functions within a particular organization and throughout the chain, to improve the performance of individual companies and all other links in the supply chain. SCM requires organizations to be responsible for sharing information on planning, management, execution, and performance measurement (Min \& Mentzer, 2004).

In general, companies adopt SCM practices to gain competitiveness in their market, as well as to reduce their costs and improve customer satisfaction (Mentzer et al., 2001). Park et al. (2004) point out the main benefits achieved by supply chain management, such as cost reduction, risk sharing, access to financial capital, complementary assets, increased learning capacity, and 
knowledge transfer. SCM contributes to waste elimination and more efficient use of internal and external capabilities and technologies by bringing competition, previously at the interorganizational level, to a level between supply chains (Paulraj \& Chen, 2007). Efficient supply chain management, participating companies enhance their operational base (Simatupang \& Sridharan, 2005) and increase their productivity (Pires, 2006).

One of the main barriers for SCM is linked to the need for the companies involved to make information that is considered strategic available to all other members of the chain (Mentzer et al., 2008). Taking this into account, it can be said that SCM actions need to overcome the information sharing barrier and are increasingly focused on integrating supply chain participants through new technologies and communication aimed at strategic and sustainable development. Operational planning ultimately benefits the end consumer with better products and services, and provides competitiveness for everyone involved in the supply chain (Bowersox \& Closs, 2004). Therefore, the companies with the best performance are those that best integrate the main internal processes with suppliers and customers, thus structuring an SCM with defined and consistent perspectives and procedures (Zhang \& Dilts, 2004).

Importantly, all companies within a supply chain have a transactional relationship with the other participating organizations. Due to the new demands, these companies develop a joint working relationship with the other firms in their chain. The financial results achieved through the partnership relationship within SCM make the companies involved more competitive. In this way, SCM becomes an important and hard-to-mimic resource for crossing barriers inside and outside an organization (Li et al., 2006).

Synthesizing the proper functioning of SCM, Cao \& Zhang (2011) defined seven interconnected dimensions:

(a) Information sharing that refers to the variety of relevant, accurate, complete, and confidential information that an organization shares with its supply chain partners on time (Sheu et al., 2006). For SCM to be efficient, greater contact between the organizations involved and greater information sharing among them is required (Sahay, 2003). For Bowersox et al. (2014), SCM contributes to information sharing and joint planning, enhancing the movement of materials, thus reducing the risks of not serving the customer.

(b) Objective congruence between supply chain partners is achieved from the moment the company, which applies SCM, realizes that its objectives are met when the objectives of the entire supply chain are also met (Simatupang \& Sridharan, 2002; Coti-Zelati \& Moori, 2015).

(c) Decision synchronization refers to the process by which an organization prepares its decision within planning in the supply chain (Adams et al., 2014). This decision should contribute to the benefit of all partners (Simatupang \& Sridharan, 2005).

(d) The alignment of incentives, according to Simatupang \& Sridharan (2008), refers to the policy of distributing costs, risks, and benefits among partners within a supply chain. For Mattos \& Laurindo (2015), the alignment of incentives requires careful management of the earnings per share structure, that is, the gain of a company must be proportional to its investment and its risk.

(e) Resource sharing is linked to the organizational process of investing and leveraging capabilities and resources in partnership with other companies in its supply chain (Christopher, 2016). According to Harland et al. (2004), as resources. we understood the physical, that is, equipment and technologies.

(f) Interorganizational communication (open, frequent, and balanced) is the contact and the process of message transmission between companies in a supply chain (Paulraj et al., 2008; Jaradat et al., 2017). 
(g) Joint knowledge creation refers to the way partners in a supply chain jointly develop a better understanding of the competitive marketplace (Malhorta et al., 2005; Marconi et al., 2017).

\section{Methodology}

This work was carried out through descriptive qualitative research. The descriptive research is based on the detailed exposure of the characteristics of a phenomenon through the use of standardized data collection techniques (Gil, 2008). According to Merriam (2002), qualitative research hopes to understand a given situation through the interpretation and experience of individuals about such context. That is, the researcher seeks to understand a situation through the logic and perspective of respondents (Godoi \& Balsini, 2010). Godoi \& Balsini (2010, p. 96) also affirm that "Qualitative methods emerge from phenomenological and interpretative paradigms [...]". Thus, no statistical means are used as the basis of the analysis process in the technique in question (Richardson, 1999).

Data were collected through a semi-structured interview script, aiming to understand how the supply chain of the agricultural machinery industry is managed, from the interviewees' point of view. The script of the interviews was based on the seven dimensions of SCM defined by Cao \& Zhang (2011) which were associated with the five logics of non-existence (monocultures) of Santos (2006) so that, from a critical perspective, it was a possible check for possible absences in the relationship between "smaller" companies and the "captain" company in the supply chain.

Interviews were conducted individually with managers of companies in the agricultural machinery and implements sector that are inserted in supply chains "captained" by the main players in the market. It is important to note that the interviewees were previously informed that this was academic research, to understand their perception of the subject and that no data regarding the company and/or the participant would be disclosed, as well as respondents could decline from the interview at any time. It was not part of the object of study, to analyze the perception of the executive employee of the companies listed as captains of the chain of agricultural machinery. In this work, and at first, interested the perspective of the employee of companies that are part of the list of suppliers of the large agricultural technology companies.

The interviews took place between April and May 2016 and were recorded with the consent of each participant formally expressed. Then, the contents of the recordings were transcribed to facilitate data analysis. Qualitative data are analyzed to identify recurrent patterns or common points in them, a characteristic procedure of categorical analysis. The intense and detailed evaluation of the results must be presented through association with the theory that supports the work (Merriam, 2002).

Richardson (1999) highlights the importance of the interpretation of the facts by the researcher, who must also synthesize the information, pointing possible trends and generalizations of meanings so that new forms of understanding are created about a certain phenomenon. According to Denzin \& Lincoln (2006), the qualitative method consists of highlighting the qualities of entities and processes, as well as the meanings, which are not examined or experimentally measured in relation to quantity, volume, intensity, or frequency. Therefore, it does not analyze the causal relationships between variables and does not have mathematical models or statistical tables for the search.

\section{Presentation and Analysis of Results}

At the time of the survey, the interviewees held executive positions in companies, with industrial units, suppliers of implements for three of the main players in the world agricultural machinery 
market, here called the fictitious names $X, Y, Z$. All employees interviewed are employees of the companies and develop a strategic role in their companies. The interview was guided so that the perspectives are not individual, but of the organization. We can assume that the answers were from the organizational culture of these companies (and not in the opinion of the interviewees) to avoid bias during data collection. In agreement with the interviewees, it was decided not to disclose their names. Table 1 presents the profile of the participants of this research.

Table 1. Characterization of respondents.

\begin{tabular}{|c|c|c|c|c|c|}
\hline Respondent & Education & Position & $\begin{array}{c}\text { Company } \\
\text { experience }\end{array}$ & Company & City \\
\hline $\mathrm{R} 1$ & $\begin{array}{l}\text { Production } \\
\text { Engineering }\end{array}$ & $\begin{array}{l}\text { Production } \\
\text { Manager }\end{array}$ & 5 years & X Supplier & $\begin{array}{c}\text { Nova Odessa } \\
\text { (SP) }\end{array}$ \\
\hline $\mathrm{R} 2$ & $\begin{array}{l}\text { Agronomical } \\
\text { Engineering }\end{array}$ & $\begin{array}{l}\text { Distribution } \\
\text { Supervisor }\end{array}$ & 4 years & X Supplier & Piracicaba (SP) \\
\hline R3 & $\begin{array}{l}\text { Mechanical } \\
\text { Engineering }\end{array}$ & $\begin{array}{l}\text { Commercial } \\
\text { Director }\end{array}$ & 8 years & Y Supplier & Curitiba (PR) \\
\hline R4 & Administration & $\begin{array}{l}\text { Production } \\
\text { Director }\end{array}$ & 14 years & Y Supplier & São Paulo (SP) \\
\hline R5 & Administration & Sales Manager & 4 years & Z Supplier & São Paulo (SP) \\
\hline R6 & $\begin{array}{l}\text { Production } \\
\text { Engineering }\end{array}$ & $\begin{array}{l}\text { Commercial } \\
\text { Manager }\end{array}$ & 9 years & Z Supplier & Jaú (SP) \\
\hline
\end{tabular}

During data collection and results analysis, we sought to relate the seven dimensions of SCM enshrined by Cao \& Zhang (2011) with the five monocultures conceptualized by Santos (2006).

\subsection{Information sharing, collaborative communication, and the knowledge monoculture}

Efficient information exchange operates as a tool to aid demand planning, as well as contributing to the elimination of activities that do not bring value to the operation by avoiding possible information congestion (Paulraj \& Chen, 2007). According to Squire et al. (2009), inter-organizational communication and information sharing among companies in the same supply chain remove obstacles for loyalty, make it possible to eliminate technical barriers to modularization, and contribute to the solution of organizational problems. Regarding data collection, the following excerpts from the interviews stand out (Table 2):

From the interviews, we can observed that actual information sharing and collaborative communication do not occur in an open and shared manner as foreseen in the SCM literature (Min \& Mentzer, 2004). The "captain" companies in the chain exchange information with their suppliers and customers, but in a very controlled manner and disregarding the knowledge and information of the smaller companies that are part of the chain. It can be seen that the "captain" seeks to extract as much knowledge from his chain without often offering all the information he already has available.

Although the monoculture of knowledge, according to Santos (2006), refers to the valorization of scientific knowledge to the detriment of other knowledge, producing the figure of the ignorant, the disregard of existing knowledge in smaller companies by dominant companies in the chain of supplies, can be characterized by the production of absence based on the concept of the monoculture of knowledge (Croissant, 2014). Failure to consider the knowledge of smaller companies to the strategic direction of the chain, making it invisible and disqualified for SCM performance, puts the knowledge of dominant companies as the only valid knowledge to be taken into consideration. 
Table 2. Excerpts from the interviews.

\begin{tabular}{|c|c|c|c|}
\hline R1 & R3 & R4 & R5 \\
\hline $\begin{array}{l}\text { Well, nice names, } \\
\text { but that's not how } \\
\text { it goes (laughs). [...] } \\
\text { In fact, we [are] who } \\
\text { make our information } \\
\text { completely available, } \\
\text { even to improve } \\
\text { the performance of } \\
\text { our chain. JD makes } \\
\text { available to its partners } \\
\text { only the information it } \\
\text { believes is necessary, } \\
\text { I don't think they want } \\
\text { to sell the fish, you } \\
\text { know? She keeps the } \\
\text { information, often } \\
\text { privileged for her to } \\
\text { outline the strategies } \\
\text { she believes are most } \\
\text { reasonable for the } \\
\text { entire chain. Much } \\
\text { of the information } \\
\text { and knowledge of the } \\
\text { market is in their hands } \\
\text { and they work out } \\
\text { their strategies on this } \\
\text { information without } \\
\text { sharing it with the rest } \\
\text { of the chain. She shares } \\
\text { the information that } \\
\text { matters, understands? } \\
\text { Valid information } \\
\text { is what JD deems } \\
\text { important for the chain } \\
\text { (emphasis added). }\end{array}$ & $\begin{array}{l}\text { [...] We share our } \\
\text { information with NH, } \\
\text { but the opposite is } \\
\text { not always true. I } \\
\text { can even say that we } \\
\text { have very effective } \\
\text { communication } \\
\text { between our } \\
\text { companies, so far } \\
\text { without problems, I just } \\
\text { think that it controls, } \\
\text { due to its strength } \\
\text { in the chain, our } \\
\text { communications, even } \\
\text { in our communication } \\
\text { and information } \\
\text { exchange with our } \\
\text { suppliers NH has } \\
\text { participation. When } \\
\text { we are going to } \\
\text { send some market- } \\
\text { related information } \\
\text { to our suppliers, it is } \\
\text { important, even if not } \\
\text { an obligation (laughs), } \\
\text { to keep NH aware (our } \\
\text { emphasis). It ends up } \\
\text { dictating the pace of } \\
\text { our production and } \\
\text { our strategies are } \\
\text { basically linked to the } \\
\text { information she has } \\
\text { about the market and } \\
\text { makes it available to the } \\
\text { chain. }\end{array}$ & $\begin{array}{l}\text { [...] all information } \\
\text { distributed or shared } \\
\text { throughout the supply } \\
\text { chain is part of NH. } \\
\text { Rarely have I noticed } \\
\text { the company interested } \\
\text { in the information or } \\
\text { knowledge we had } \\
\text { available (our emphasis) } \\
\text { [...] obviously NH has } \\
\text { a strong structure and } \\
\text { we can almost always } \\
\text { rely on the information } \\
\text { extracted and shared by } \\
\text { it [...] of strategies, we } \\
\text { stand aside, just waiting } \\
\text { for the decisions (our } \\
\text { emphasis). }\end{array}$ & $\begin{array}{l}\text { I think CIH, like } \\
\text { many other large } \\
\text { companies, controls } \\
\text { the information and } \\
\text { knowledge generated } \\
\text { in the supply chain to } \\
\text { use as it understands } \\
\text { it, always aiming at its } \\
\text { performance (emphasis } \\
\text { added). We have our } \\
\text { research and market } \\
\text { development, but the } \\
\text { market knowledge } \\
\text { generated ends up } \\
\text { being the one dictated } \\
\text { by CIH. Our chain } \\
\text { ends up using the } \\
\text { information aimed at } \\
\text { the strategies of CIH. } \\
\text { Good or bad, we have } \\
\text { nothing to complain } \\
\text { about, the success of } \\
\text { our biggest customer is } \\
\text { our success (laughs). }\end{array}$ \\
\hline
\end{tabular}

\subsection{Congruence in objectives and the productivity logic}

According to Lejeune \& Yakova (2005), it is possible to define two situations of congruence in the objectives. In the first, what is meant as true congruence in objectives, where the company understands that its objectives fully coincide with the objectives of its partners. In the second, there is a case of disparity, that is, the organization believes that its objectives will be achieved as a direct result of the work promoted towards the supply chain objectives.

The following excerpts from the interviews are highlighted (Table 3):

It is possible to perceive, through the excerpts of the highlighted interviews that the goal of the chain ends up being, even indirectly, the goal of the "captain" of the chain. This large company has the search for competitive advantage in its sector as its main objective, which is subordinated to the production of the other members of the chain. The productivist logic is based on the monoculture of the capitalist productivity criteria (Vieira \& Ramos, 2018). The nature of production is the force in a given productive cycle, that is, truly productive work is the one that generates profit in this productive cycle. At SGM, the subordinate company that meets the objectives of the captain company "otherwise we are a card out of the deck" is productive (R5). Absence, in this situation, is produced in the form of unproductivity, and disqualification, in analogy with the absence produced by the productivist logic (Santos, 2002). 
Table 3. Excerpts from the interviews.

\begin{tabular}{|c|c|c|c|}
\hline R1 & R2 & R3 & R5 \\
\hline $\begin{array}{l}\text { There is no congruence } \\
\text { in the goals (laughs), } \\
\text { this is a little dream, } \\
\text { understand? JD has } \\
\text { its clear goals that it } \\
\text { is to win the largest } \\
\text { number of customers } \\
\text { and remain the first } \\
\text { in the industry [...] Of } \\
\text { course, we are very } \\
\text { interested in being part } \\
\text { of its partner team, } \\
\text { so I can tell you that } \\
\text { our main objective is } \\
\text { to stay as a supplier } \\
\text { of JD, understand? As } \\
\text { much as we don't put } \\
\text { this on our sites and } \\
\text { we don't tell anyone. } \\
\text { [...] We often go over } \\
\text { some of our possible } \\
\text { goals to meet the larger } \\
\text { goal that is JD (our } \\
\text { emphasis), she wants } \\
\text { to continue to be the } \\
\text { leading company in the } \\
\text { industry and maintain } \\
\text { its competitiveness at } \\
\text { all costs. Our goal is } \\
\text { to work to ensure that } \\
\text { JD keeps its goal alive } \\
\text { (emphasis added). }\end{array}$ & $\begin{array}{l}\text { [...] I believe the goals } \\
\text { are congruent, but } \\
\text { fatally our goals end } \\
\text { up tied to the goals } \\
\text { of JD. It has a huge } \\
\text { corporate structure and } \\
\text { can clearly define the } \\
\text { objectives of its chain } \\
\text { [...] they are strong and } \\
\text { have great productive } \\
\text { potential, we do not } \\
\text { have the size of a giant } \\
\text { company to be able to } \\
\text { face when the goals are } \\
\text { set. We are waiting to } \\
\text { know how to act and } \\
\text { from there, offer, as } \\
\text { a supplier, everything } \\
\text { she needs to reach her } \\
\text { goals (emphasis added). } \\
\text { It's the way to reach } \\
\text { ours too, in a way. }\end{array}$ & $\begin{array}{l}\text { [...] In the agricultural } \\
\text { machinery sector } \\
\text { there is very strong } \\
\text { competitiveness, } \\
\text { there are few major } \\
\text { companies in the } \\
\text { sector, this in the world, } \\
\text { so there is a big market } \\
\text { to be explored and the } \\
\text { fight for a bigger and } \\
\text { better market share is } \\
\text { constant. Our company } \\
\text { aims to grow, develop, } \\
\text { invest in new business, } \\
\text { but in the background, } \\
\text { our primary goal is to } \\
\text { serve NH in the way } \\
\text { it wants to be served } \\
\text { and to help it reach } \\
\text { and maintain market } \\
\text { competitiveness. with } \\
\text { great products (our } \\
\text { emphasis). }\end{array}$ & $\begin{array}{l}\text { [...] CIH has its } \\
\text { objectives well defined } \\
\text { as one of the main } \\
\text { brands of agricultural } \\
\text { machines on the planet. } \\
\text { Fight for more market } \\
\text { conquest against its } \\
\text { main competitors NH, } \\
\text { even from the Fiat and } \\
\text { JD group. To partner } \\
\text { with CIH, we have to } \\
\text { understand and absorb } \\
\text { its goals. [...] It is a } \\
\text { daily struggle for more } \\
\text { competitiveness and } \\
\text { we, suppliers in your } \\
\text { supply chain, we have } \\
\text { to understand this and } \\
\text { help it to achieve this } \\
\text { competitive position, } \\
\text { otherwise we are } \\
\text { letter out of the deck } \\
\text { (emphasis added). }\end{array}$ \\
\hline
\end{tabular}

\subsection{Decision synchronization and social classification logic}

Joint planning is used for the alignment of partners, aimed at synchronizing operational decisions such as stock replenishment, order, and delivery (Cao \& Zhang, 2011). Regarding this theme, the following excerpts from the interviews can be highlighted (Table 4):

From the interviews, we observed that there is a social classification within the agricultural machinery supply chain. The "captain" companies in their chains make independent decisions of the smaller companies (eg suppliers) who, in turn, are convinced and resigned to the situation and even admit to some degree that they are "inferior", showing naturalization differences and hierarchy within the supply chain. The naturalization of the supply chain hierarchy leads, in the opinion of the interviewees, to invisibility of the smaller organizations of which they are part, with regard to shared strategic decision-making.

Sharing strategic decisions gives way to submission to the captain company's strategies. According to Santos (2002), the logic of social classification is the distribution of populations by categories that naturalize hierarchies. The domain relationship is a consequence (not the cause) of the hierarchy and is understood as an obligation for those who are considered "superior". In this case, absence is produced in the form of inferiority (insurmountable), and who is "inferior" cannot offer a reliable alternative (Bernandes \& Ventura, 2017). 
Table 4. Excerpts from the interviews.

\begin{tabular}{|c|c|c|c|}
\hline R1 & R2 & R3 & R5 \\
\hline $\begin{array}{l}\text { I can tell you quite } \\
\text { safely that there is no } \\
\text { synchronization in our } \\
\text { supply chain decisions } \\
\text { (laughs). Any decision, } \\
\text { at least in our company, } \\
\text { is defined after a } \\
\text { decision by JD (laughs) } \\
\text { (emphasis added). We } \\
\text { are small fish near } \\
\text { them, so decisions can } \\
\text { follow and must follow } \\
\text { a coherence, after all, } \\
\text { we are part of the same } \\
\text { chain, but there is no } \\
\text { synchronization. We } \\
\text { move when JD makes } \\
\text { its decision and her } \\
\text { decision is the decision } \\
\text { of the chain in which } \\
\text { she is inserted. She } \\
\text { dominates the market, } \\
\text { the chain, and the } \\
\text { decisions. }\end{array}$ & $\begin{array}{l}\text { I can't tell if } \\
\text { synchronization occurs } \\
\text { in decisions, but it } \\
\text { seems to be quite } \\
\text { utopian. In our industry, } \\
\text { the big company, the } \\
\text { big automaker, makes } \\
\text { the decision that's } \\
\text { most convenient for } \\
\text { her, without caring } \\
\text { much, you know, with } \\
\text { the smaller companies } \\
\text { (our emphasis) that are } \\
\text { part of its structure. } \\
\text { We are informed of } \\
\text { strategic decisions and } \\
\text { act to meet whatever } \\
\text { it takes to avoid losing } \\
\text { the customer, right?! } \\
\text { (laughs). }\end{array}$ & $\begin{array}{l}\text { [...] NH is not very } \\
\text { concerned about this } \\
\text { synchronization; she } \\
\text { points and presents } \\
\text { to the chain which or } \\
\text { what will be its strategic } \\
\text { decisions and we mere } \\
\text { mortals (laughs) have to } \\
\text { follow (our emphasis). } \\
\text { That is, there is even a } \\
\text { synchronization, but it is } \\
\text { a synchronization that } \\
\text { follows the decisions } \\
\text { previously determined } \\
\text { by NH, is difficult, and } \\
\text { it is not our intention to } \\
\text { determine the direction } \\
\text { of decisions of the chain } \\
\text { as a whole, leaving it } \\
\text { to them that has more } \\
\text { market strength [...] }\end{array}$ & $\begin{array}{l}\text { I don't see much of } \\
\text { this synchronization } \\
\text { in the decisions in our } \\
\text { chain. What I perceive } \\
\text { most is a hierarchy of } \\
\text { decisions that end up } \\
\text { affecting the whole } \\
\text { chain (emphasis } \\
\text { added). CIH makes } \\
\text { strategic decisions } \\
\text { aimed at the market } \\
\text { and competitiveness } \\
\text { against other } \\
\text { companies that } \\
\text { dominate the } \\
\text { agricultural machinery } \\
\text { market on the planet, } \\
\text { it is up to the supplier } \\
\text { to simply follow the } \\
\text { decisions made by CIH } \\
\text { if they want to be part } \\
\text { of the club (laughs). } \\
\text { It is not a complaint, } \\
\text { we are interested } \\
\text { in serving CIH with } \\
\text { excellence, which as I } \\
\text { said earlier, is our main } \\
\text { customer, so we accept } \\
\text { the market decisions } \\
\text { made by it and try to } \\
\text { do the impossible to } \\
\text { meet it in its demand } \\
\text { and challenges. }\end{array}$ \\
\hline
\end{tabular}

\subsection{Incentive alignment, resource sharing, and the logic of the dominant scale}

According to Cao \& Zhang (2011), for SCM to be successful, incentives must be aligned, that is, each participating company must share gains and losses equally. Resource sharing is directly related to the joint investment process between partner companies, within the supply chain, aimed at enhancing organizational capabilities and resources. This aspect is of fundamental importance for SCM efficiency (Cao \& Zhang, 2011). In this sense, the following excerpts from the interviews stand out (Table 5):

Through the interviewees' speech, we noticed a relationship between the dimensions of incentive alignment and resource sharing with the monoculture known as the logic of the dominant scale. If the captain company wins, all member companies in the chain win, but not to the same extent and get lost, the costs are socialized. However, if a non-captain company loses, the resulting costs are not socialized. According to Ferrarini (2018), in this logic of non-existence production, the scale adopted as primordial and successful determines, as a consequence, the other existing scales as irrelevant. Private entities are trapped in scales that are not considered dominant, which incapacitates them from being considered as credible alternatives (Santos, 2002). 
Table 5. Excerpts from the interviews.

\begin{tabular}{|c|c|c|c|}
\hline R1 & R3 & R5 & R6 \\
\hline $\begin{array}{l}\text { [...] we have this } \\
\text { alignment with JD, we } \\
\text { share success and } \\
\text { failure within the chain, } \\
\text { I only see an interesting } \\
\text { detail in this respect } \\
\text { (silence) we share the } \\
\text { success and failures of } \\
\text { JD and not the chain, ie } \\
\text { The whole chain enjoys } \\
\text { JD's gains or suffers } \\
\text { her losses. Incentive } \\
\text { alignment is tied to JD's } \\
\text { success or failure, JD } \\
\text { doesn't share my losses, } \\
\text { my losses are mine } \\
\text { alone, my gains are } \\
\text { theirs, you know? (our } \\
\text { emphasis). So there } \\
\text { is an alignment and } \\
\text { sharing of incentives, } \\
\text { but always aiming at } \\
\text { the greater interest of } \\
\text { JD. }\end{array}$ & $\begin{array}{l}\text { [...] It is difficult to } \\
\text { think about sharing } \\
\text { gains, investments, } \\
\text { and losses. NH offers } \\
\text { to the market state- } \\
\text { of-the-art agricultural } \\
\text { machines of excellent } \\
\text { quality, because, of } \\
\text { course, if its product } \\
\text { does not go well in the } \\
\text { market, this generates } \\
\text { a loss, generates a cost } \\
\text { and this cost is diluted } \\
\text { in the chain, so we } \\
\text { suffer the reflections of } \\
\text { problems at the end of } \\
\text { the chain. But I cannot } \\
\text { say that a problem of } \\
\text { my company, which } \\
\text { generates a cost or a } \\
\text { failure, I can share with } \\
\text { NH (emphasis added). }\end{array}$ & $\begin{array}{l}\text { We have to see this } \\
\text { resource sharing on } \\
\text { two sides. The first is } \\
\text { the CIH side. She seeks } \\
\text { to understand which } \\
\text { resources available in } \\
\text { the chain may be critical } \\
\text { to her performance. } \\
\text { It sounds like an } \\
\text { individualistic view, but } \\
\text { unfortunately, the rule } \\
\text { of the game is this. The } \\
\text { CIH seeks to extract from } \\
\text { the chain everything } \\
\text { that can contribute } \\
\text { to its organizational } \\
\text { development and share } \\
\text { with the chain what } \\
\text { matters, that is, there } \\
\text { is always an ace under } \\
\text { the sleeve (laughs) } \\
\text { (emphasis added). It does } \\
\text { not fully open to chain } \\
\text { partners. The alignment } \\
\text { of incentives exists. } \\
\text { Obviously, if ICH wins, } \\
\text { we win, not to the same } \\
\text { extent, of course. If we } \\
\text { think of losses, I believe } \\
\text { the metric is the same, } \\
\text { but inverse (laughs). }\end{array}$ & $\begin{array}{l}\text { [...] It is important to } \\
\text { say that we depend } \\
\text { on CIH, if it goes bad, } \\
\text { we will lose market } \\
\text { and space. If we have } \\
\text { problems like this, our } \\
\text { recovery, that is, the } \\
\text { gap is much larger } \\
\text { (emphasis added). [...] } \\
\text { the large company, } \\
\text { can overcome a } \\
\text { difficult phase of the } \\
\text { market, our company } \\
\text { is not of this size, so we } \\
\text { cannot afford to make } \\
\text { mistakes. We couldn't } \\
\text { stand the jolt (laughs). }\end{array}$ \\
\hline
\end{tabular}

\subsection{Joint knowledge creation and the monoculture of linear time}

Creating knowledge, whether technological, process, or market, among partner organizations in a supply chain enables greater innovation power, making the chain more competitive for longer (Johnson \& Sohi, 2003). For this topic, the following excerpts from the interviews are highlighted (Table 6):

The discussion about the dimension related to the joint creation of knowledge, from the collected interviews, refers to the logic of non-existence production called a monoculture of linear time. The monoculture of linear time brings the idea that there is a unique sense of direction for knowledge. This direction has been constituted by Western-capitalist thinking and aims at progress, development, modernization, and globalization. Following this perspective, it is possible to observe that valid and dominant knowledge is born in the central countries of the capitalist system (Paes \& Dellagnelo, 2012).

This logic disqualifies all asymmetrical knowledge to thought understood as advanced and reliable (Santos, 2002). At SCM, valid knowledge, as has been said in addressing information sharing, collaborative communication, is knowledge developed by the captain company. This knowledge is an attempt to ensure the competitiveness and future existence of this company, and consequently, the future of other companies in the supply chain. The future of these companies is linked to the future of the captain company, as the only possible future, referring to the linear time monoculture, pointing to the conception that the future is determined by the dominant company of the chain (Santos, 2002). 
Table 6. Excerpts from the interviews.

\section{R1}

We do not participate in JD research and development projects; no innovation projects are discussed with our company [...]. All knowledge that has any value for building innovative strategies comes from themselves, there is little or no open discussion about where our market should go and how we should deal with market trends. All research is developed and evaluated by JD, what remains is to believe that her decisions lead us to success (laughs) (emphasis added).

\section{R3}

I do not recall attending any meetings or meetings where it was probed to create joint supply chain knowledge. [...] when I think of $\mathrm{NH}$ I don't see the possibility of joint knowledge creation that focuses on chain development, unless indirectly, but I see a gathering of all knowledge in the chain to generate an own knowledge that must be distributed throughout the chain to generate competitiveness, profit and market for itself first and then for the common development of the chain (emphasis added).

\section{Discussion of Results}

The results generated two aspects regarding SCM: one dealing with the divergence between the normative and practical approach in SCM and the other about the consequences of these practices on the supply chain companies, promoting the visibility of the captain company and the invisibility of other companies that form the chain links.

The dimensions proposed by Cao \& Zhang (2011) to define supply chain presuppose a balance of forces that lead to information sharing, congruence of objectives among partner companies, information synchronization, incentive alignment, information sharing. resources, communication, and the joint creation of knowledge. For the supply chain to be translated by these dimensions, the assumption of the ecology of knowledge is necessary (Santos, 2006), through the recognition of the existence and the capacity of action of each collectivity, in the case of partner companies in favor of common goals. The results of this research, however, indicated that the supply chain management of the agricultural machinery and implements sector is influenced by the macro-sociological investigation procedure defined as the sociology of absences.

The investigation of the practice of supply chain management dimensions defined by Cao \& Zhang (2011) showed characteristics related to the monocultures defined by Santos (2006), whether it is the monoculture of knowledge produced by the captain company, generating lack of recognition of knowledge of the other companies that produce for him; either by the productivist logic, in which the production is valid only if it meets the company that commander; or by the monoculture of linear time in which the future of the chain companies is predicted and contained in the future of the parent company, or by the naturalization of differences, promoting the social classification, in which some companies are more important than others. All these monocultures are determined by the logic of the dominant scale.

In his research, Boaventura de Sousa Santos points to the need to change rationality, especially discovering categories that help to observe life beyond the lens of the established hegemonic standard. Santos, in his works, criticizes the dominant Western rationality model and if nothing changes all the proposals presented by a new social analysis, however efficient and alternative it may be will remain uncredited, hidden, and absent (Santos, 2000). 
The reinvention of the supply chain as a knowledge network, under the conception of knowledge ecology proposed by Santos (2006) implies reciprocity, and therefore, the construction of a network of horizontal relationships in which the availability for mutual enrichment is present, resulting in the expansion of knowledge, the empowerment of companies participating in the network and the competitive strengthening of the entire network. Sharing in building the vision and strategic direction of the business, with the participation of all companies involved, also implies the sharing of responsibilities and commitment of all companies involved. The change in the concept of the supply chain to supply chain, in light of the ecology of knowledge proposed by Boaventura Santos throughout his extensive work, implies a change in management, becoming the Shared Management of the supply chain.

\section{Conclusions}

The biggest challenge of applied social science research is to try to break away from the uniform and hegemonic model, based on the western process of neoliberal globalization. According to Boltanski \& Chiapello (1999), it is not difficult to realize that society has reached a limit point where it can no longer generate wealth without, at the same time, generating absence, exclusion, social inequality, environmental damage, construction of standardized thinking. Scientific work focused on the study of SCM goes through this critical moment. These are surveys that generally focus on the interest of the few organizations that have the most power within the supply chains in which they operate.

The objective of this research was to understand how the supply chain of the agricultural machinery industry is managed, taking as its analysis the sociology of absences. To this end, qualitative descriptive empirical research was developed with the participation of six executives of implement suppliers for the three main agricultural machinery companies worldwide.

Empirical research of descriptive type was carried out, of qualitative nature with the participation of six interviewees (executives) of six organizations that are members of the supply chain of the agricultural machinery industry. During the research, we sought to understand and relate the dimensions of sociology of absences in the supply chain management of the agricultural machinery industry from the perspective of executives of supplier companies of three of the main players in the agricultural machinery sector.

Building the relationship between supply chain employees in the light of the sociology of absences brings some points for reflection. The first is the need to decolonize developmental logic and knowledge, making legitimate the many hidden experiences in the agricultural machinery supply chain that were initially considered unreliable. The second points to the need to reinvent the supply chain configuration, to become a supply chain and meet the assumptions of sharing and alignment of interests, where each company has its knowledge and identity recognized and respected, as Cao \& Zhang (2011).

The sociology of absences, as an analytical category can unveil the practice of SCM in other segments and contribute to the development of knowledge about SCM, seeking to enrich and broaden the frontiers of thinking contributing to understand and review the functioning and configuration of supply chains.

The results of this study provided relevant data that can be used to assess SCM's absences from the agricultural machinery industry. In addition, it can help to understand the benefits of the evolution of the currently applied SCM model, seeking a more balanced social development among all participating links in the agricultural machinery supply chain. Even though a supplier is a producer of low value-added ins ums and depends on the captain company (probably its 
master client), its strategic perspective of the market in which the chain is constituted could be exploited by the captain for the consolidation of efficiency and greater operational performance. In principle, supply chain management is based on the idea of a certain "partnership", so this partnership could become an even more robust strategic alliance for the solidification of strategies that would benefit all links in the chain.

It was not part of the object of this study to analyze the perspective of the suppliers who provide for these companies that were part of the research. Eventually, one of these participating companies may appear with "captain" in another chain, but this work boils down to observing and analyzing the main chain of machinery and agricultural implement (where are the main players).

For future studies, we suggest: (a) new field research to understand supplier-customer relationships in parallel chains or correlated to the chain of agricultural machines urments; (b) the perception of executives of the companies treated in this study as "captains" to better understand the issues presented here; (c) longitudinal cutting research to construct correlations and to verify whether, after a few years, this perspective is different.

\section{References}

Adams, F. G., Richey Junior, R. G., Autry, C. W., Morgan, T. R., \& Gabler, C. B. (2014). Supply chain collaboration, integration, and relational technology: how complex operant resources increase performance outcomes. Journal of Business Logistics, 35(4), 299-317. http://dx.doi. org/10.1111/jbl.12074

Barney, J. B., \& Hesterly, W. S. (2012). Strategic management and competitive advantage. Pearson.

Bernandes, E. M., \& Ventura, C. A. (2017). A. Sociology of Absences as a theoretical reference for research in Psychiatric nursing and in mental health. Texto \& Contexto Enfermagem, 26(4), 1-11.

Boltanski, L., \& Chiapello, E. (1999). Le nouvel esprit du capitalism. Gallimard.

Bowersox, D. J., \& Closs, D. J. (2004). Logística empresarial: o processo de integração da cadeia de suprimentos. Atlas.

Bowersox, D. J., Closs, D. J., Cooper, M. B., \& Bowersox, J. C. (2014). Gestão logística de cadeia de suprimentos (4. ed). Bookman.

Cao, M., \& Zhang, Q. (2011). Supply chain collaboration: impact on collaborative advantage and firm performance. Journal of Operations Management, 29(3), 163-180. http://dx.doi. org/10.1016/j.jom.2010.12.008

Comte, A. (1973). Curso de filosofia positiva, discurso sobre o espírito positivo, discurso preliminar sobre o conjunto do positivismo e catecismo positivista. In V. Civita (Org.), Os pensadores. Abril Cultural.

Coti-Zelati, P. E., \& Moori, R. G. (2015). O papel da colaboração no desempenho da gestão da cadeia de suprimentos: um estudo sobre o café orgânico. Organizações Rurais \& Agroindustriais, 17(2), 195-208.

Choi, T. Y., \& Wu, Z. (2009). Triads in supply networks: theorizing buyer-supplier-supplier relationships. The Journal of Supply Chain Management, 45(1), 8-25. http://dx.doi. org/10.1111/j.1745-493X.2009.03151.x

Christopher, M. (2016). Logistics and supply chain management (5th ed). Pearson. 
Croissant, J. (2014). Agnotology: ignorance and absence or towards a sociology of things that aren't there. Journal Social Epistemology, 28(1), 4-25. http://dx.doi.org/10.1080/02691728 .2013 .862880

Denzin, N. K., \& Lincoln, Y. S. (2006). O planejamento da pesquisa qualitativa: teorias e abordagens (2. ed). Artmed.

Dussel, E. (2000). Ética de la liberación en la edad de la globalización y de la exclusión. Trotta.

Ferrarini, A. V. (2018). Sociologia das ausências e das emergências na análise teórico-epistemológica de uma política pública participativa. Revista de Ciencias Sociales, 49(1), 400-425.

Gil, A. C. (2008). Métodos e técnicas de pesquisa social(6. ed). Atlas.

Godoi, C. K., \& Balsini, C. P. V. (2010). A pesquisa qualitativa nos estudos organizacionais brasileiros: uma análise bibliométrica. In C. K. Godoi, R. Bandeira-De-Mello \& A. B. Silva (Orgs.), Pesquisa qualitativa em estudos organizacionais: paradigmas, estratégias e métodos (2. ed). Saraiva.

Harland, C. M., Zheng, J., Johnsen, T. F., \& Lamming, R. C. (2004). A conceptual model for researching the creation and operation of supply network. British Journal of Management, 15(1), 1-21. http://dx.doi.org/10.1111/j.1467-8551.2004.t01-1-00397.x

Jaradat, R., Adams, F. G., Abutabenjeh, S., \& Keating, C. (2017). The complementary perspective of system of systems in collaboration, integration, and logistics: a value-chain based paradigm of supply chain management. Systems, 5(4), 50. http://dx.doi.org/10.3390/systems5040050

Johnson, J. J., \& Sohi, R. S. (2003). The development of interfirm partnering competence: platforms for learning, learning activities and consequences of learning. Journal of Business Research, 56(9), 757-766. http://dx.doi.org/10.1016/S0148-2963(01)00260-0

Kopczak, L. R., \& Johnson, M. E. (2003). The supply-chain management effect. MIT Sloan Management Review, 44(3), 27-34.

Kouvelis, P., Chambers, C., \& Wang, H. (2006). Supply chain management research and production and operations management: review, trends, and opportunities. Production and Operations Management, 15(3), 449-469. http://dx.doi.org/10.1111/j.1937-5956.2006.tb00257.x

Lejeune, N., \& Yakova, N. (2005). On characterizing the 4 Cs in supply chain management. Journal of Operations Management, 23(1), 81-100. http://dx.doi.org/10.1016/j.jom.2004.09.004

Li, S., Ragu-Nathan, B., Ragu-Nathan, T. S., \& Subba Rao, S. (2006). The impact of supply chain management practices on competitive advantage and organizational performance. Omega, 34(2), 107-124. http://dx.doi.org/10.1016/j.omega.2004.08.002

Machado, C. J. S., Mello, M. B. C., \& Branquinho, F. (2012). Uma aproximação teórica entre os postulados do ideal de sustentabilidade e a Sociologia das Ausências de Boaventura Sousa Santos. Revista Brasileira de Gestão e Desenvolvimento Regional, 8(1), 288-310.

Machado, M. M., \& Teixeira, M. L. M. (2017). Dignity in the context of organizations: A look beyond modernity. Mackenzie Management Review, 18(2), 80-103. http://dx.doi.org/10.1590/167869712016/administracao.v18n2p80-103

Malhorta, A., Gosain, S., \& El Sawy, O. A. (2005). Absorptive capacity configurations in supply chains: gearing for partner-enabled market knowledge creation. Management Information Systems Quarterly, 29(1), 145-187. http://dx.doi.org/10.2307/25148671

Mattos, C. A., \& Laurindo, F. J. B. (2015). Collaborative platforms for supply chain integration: trajectory, assimilation of platforms and results. Journal of Technology Management \& Innovation, 19(1), 79-92. http://dx.doi.org/10.4067/S0718-27242015000200006 
Marconi, M., Marilungo, E., Papetti, A., \& Germani, M. (2017). Traceability as a means to investigate supply chain sustainability: the real case of a leather shoe supply chain. International Journal of Production Research, 55(22), 6638-6652. http://dx.doi.org/10.1080/00207543. 2017.1332437

Medeiros, A. L., \& Teixeira, M. L. M. (2018). A potencialidade do pensamento de Boaventura Santos para os Estudos Organizacionais. Revista de Ciências da Administração, 20(50), 166-177. http://dx.doi.org/10.5007/2175-8077.2018v20n50p166

Mello, M. B. C. (2008) Diferentes lógicas no ensinar e no aprender: por uma pedagogia das ausências. In R. L. Garcia \& E. Zaccur (Orgs.), Alfabetização: reflexão sobre saberes docentes e saberes discentes. Cortez Editora.

Mentzer, J. T., Dewitt, W., Keebler, J. S., Min, S., Nix, N. W., Smith, C. D., \& Zacharia, Z. G. (2001). Defining supply chain management. Journal of Business Logistics, 22(2), 1-25. http://dx.doi. org/10.1002/j.2158-1592.2001.tb00001.x

Mentzer, J. T., Stank, T. P., \& Esper, T. L. (2008). Supply chain management and its relationship to logistics, marketing, production and operation management. Journal of Business Logistics, 29(1), 31-46. http://dx.doi.org/10.1002/j.2158-1592.2008.tb00067.x

Merriam, S. B. (2002). Qualitative research in practice: examples for discussion and analysis. Jossey-Bass.

Mignolo, W. (2000). Local histories/Global designs: coloniality, subaltern knowledges and border thinking. Princeton University Press.

Min, S., \& Mentzer, J. T. (2004). Developing and measuring supply chain management concepts. Journal of Business Logistics, 25(1), 63-99. http://dx.doi.org/10.1002/j.2158-1592.2004. tb00170.x

Park, N. K., Mezias, J. M., \& Song, J. (2004). A resource-based view of strategic alliances and firm value in the electronic marketplace. Journal of Management, 30(1), 7-27. http://dx.doi. org/10.1016/j.jm.2002.11.001

Paes, K. D., \& Dellagnelo, E. H. L. (2012). Boaventura de Souza Santos e Guerreiro Ramos: um olhar crítico sobre as ausências e emergências em organizações. In Anais do XXXVI Encontro da Associação Nacional de Pós-Graduação e Pesquisa em Administração (EnANPAD). Rio de Janeiro: ANPAD.

Paulraj, A., \& Chen, I. J. (2007). Strategic buyer-supplier relationships, information technology and external logistics integration. The Journal of Supply Chain Management, 48(2), 2-14. http://dx.doi.org/10.1111/j.1745-493X.2007.00027.x

Paulraj, A., Lado, A. A., \& Chen, I. J. (2008). Inter-organizational communication as a relational competency: antecedents and performance outcomes in collaborative buyer-supplier relationships. Journal of Operations Management, 26(1), 45-64. http://dx.doi.org/10.1016/j. jom.2007.04.001

Pires, S. R. I. (2006). Gestão da cadeia de suprimentos: conceitos, estratégias, práticas e casos (3.ed). Atlas.

Pizzio, A., \& Veronese, M. V. (2008). Possibilidades conceituais da sociologia das ausências em contextos de desqualificação social. Cadernos de Psicologia Social do Trabalho, 11(1), 51 67. http://dx.doi.org/10.11606/issn.1981-0490.v11i1p51-67

Richardson, R. J. (1999) Pesquisa social: métodos e técnicas. Atlas.

Sahay, B. S. (2003). Supply chain collaboration: the key to value creation. Work Study, 52(1), 76-83. http://dx.doi.org/10.1108/00438020310462872 
Santiago, C., \& Machado, M. M. (2015). Implicações da globalização no âmbito do saber e da prática de gestão: algumas reflexões. Revista de Estudos de Gestão. Información Tecnológica, 2(4), 13-33.

Santos, B. S. (2000). A crítica da razão indolente: contra o desperdício da experiência. Cortez.

Santos, B. S. (2002). Para uma sociologia das ausências e uma sociologia das emergências. Revista Critica de Ciencias Sociais, 63(63), 237-280. http://dx.doi.org/10.4000/rccs.1285

Santos, B. S. (2004). Do pós-moderno ao pós-colonial e para além de um e outro. Centro de Estudos em Ciências Sociais.

Santos, B. S. (2006). A gramática do tempo: por uma nova cultura política. Cortez.

Santos, B. S. (2010a). Pela mão de Alice: o social e o político na pós-modernidade(13. ed.). Cortez.

Santos, B. S. (2010b). Um ocidente não-ocidentalista? A filosofia à venda, a douta ignorância e a aposta de Pascal. In B. S. Santos \& M. P. Meneses (Orgs.), Epistemologias do sul. Cortez.

Sheu, C., Yen, H. R., \& Chae, D. (2006). Determinants of supplier-retailer collaboration: evidence from an international study. International Journal of Operations \& Production Management, 26(1), 24-49. http://dx.doi.org/10.1108/01443570610637003

Silva, R. R. C. C., \& Moretto Neto, L. (2016). A gestão social a partir do olhar crítico da sociologia das ausências e da sociologia das emergências de Boaventura de Sousa Santos. Administração Pública e Gestão Social, 8(1), 27-37. http://dx.doi.org/10.21118/apgs.v1i1.911

Simatupang, T. M., \& Sridharan, R. (2002). The collaborative supply chain. International Journal of Logistics Management, 13(1), 15-30. http://dx.doi.org/10.1108/09574090210806333

Simatupang, T. M., \& Sridharan, R. (2005). An integrative framework for supply chain collaboration. International Journal of Logistics Management, 16(3), 257-274. http://dx.doi. org/10.1108/09574090510634548

Simatupang, T. M., \& Sridharan, R. (2008). Design for supply chain collaboration. Business Process Management Journal, 14(3), 401-418. http://dx.doi.org/10.1108/14637150810876698

Simchi-Levi, D., Kaminsky, P., \& Simchi-Levi, E. (2010). Cadeia de suprimentos: projeto e gestão (3. ed). Bookman.

Squire, B., Cousins, P. D., Lawson, B., \& Brown, S. (2009). Benefiting from suppliers capabilities: empirical evidence for the extended resource-based-view of the firm. International Journal of Operations \& Production Management, 29(8), 766-788.

Veronese, M. V. (2005). Análise de um empreendimento de economia solidária sob a ótica da sociologia das ausências e das emergências. Ciências Sociais Unisinos, 41(2), 89-99.

Vieira, A. B., \& Ramos, I. O. (2018). Dialogues between Boaventura de Sousa Santos, special education and curriculum. Educação e Realidade, 43(1), 131-150. http://dx.doi. org/10.1590/2175-623667534

Weber, R. (2004). The rhetoric of positivism versus interpretivism: a personal view. Management Information Systems Quarterly, 28(1), 3-12. http://dx.doi.org/10.2307/25148621

Zhang, Y., \& Dilts, D. (2004). System dynamics of supply chain network organization structure. Information Systems and e-Business Management, 2(2-3), 187-206. http://dx.doi.org/10.1007/ s10257-004-0036-4 